\title{
GAMBARAN HISTOPATOLOGIS LAMBUNG TIKUS WISTAR (RATTUS NOVERGICUS) YANG DIBERIKAN ALKOHOL
}

\author{
${ }^{1}$ Dewi Febry Kololu \\ ${ }^{2}$ Poppy M. Lintong \\ ${ }^{2}$ Lily Loho
}

\author{
${ }^{1}$ Kandidat skripsi Fakultas Kedokteran Universitas Sam Ratulangi \\ ${ }^{2}$ Bagian Patologi Anatomi Fakultas Kedokteran Universitas Sam Ratulangi Manado \\ Email: dewikololu14@gmail.com
}

\begin{abstract}
Alcohol has become aglobal problem. When it is consumed alcohol can disrupt the structure and function of the digestive tract. Objective: To reveal the histopathological features of the gastric of Wistar rats that are administered with bir, wine, whisky and cap tikus. Method: Experimental research using 15 rats that ware fasted and divided into 5 groups those are group control group which was treated by water, group A which was treated by beer $(4.9 \%$ alcohol),group B which was treated by wine (14\% alcohol), group C which was treated by whiskey (43\% alcohol), and group D rats which wastreated by cap tikus( $70 \%$ alcohol). The treatment of the test animals is done in 5 days. Results:In the control group on mucosa, submucosa, muscularis and serosa layers,inflammatory cells are also seen.In group Ainflammatory cells found on submucosal layer, intestinal metaplasia, and dilation of blood vessels. In group B inflammatory cell, intestinal metaplasia and dilation of blood vessels are found.In group C erosion, inflammatory cells, intestinal metaplasia and dilation of blood vessels are found.In group D submucosal necrosis, inflammatory cells, intestinal metaplasia and hyperemia are found. Conclusions: The provision of alcoholic drinks (beer, wine, whiskey, and cap tikus) in wistar can cause acute gastritis and of the high alcohol content (70\% alcohol content)will be accompanied by gastric necrosis.
\end{abstract}

Keywords: Beer, wine, whisky, cap tikus, gastritis.

Abstrak: Alkohol telah menjadi masalah global. Ketika dikonsumsi, alkohol dapat mengganggu struktur dan fungsi dari saluran pencernaan. Tujuan: Untuk mengetahui gambaran histopatologi lambung tikus wistar yang diberikan bir, minuman anggur, whisky, dan cap tikus. Metode: Penelitian eksperimental menggunakan 15 ekor wistar yang dipuasakan kemudian dibagi menjadi 5 kelompok yaitu kelompok kontrol diberi minum air, kelompok A diberi perlakuan bir (kadar alkohol 4,9\%), kelompok B diberi perlakuan anggur (kadar alkohol 14\%), kelompok C diberi perlakuan whisky (kadar alkohol 43\%), kelompok D diberi perlakuan cap tikus (kadar alkohol 70\%). Perlakuan hewan uji selama 5 hari. Hasil: Pada kelompok kontrol tampak lapisan mukosa, submukosa, muskularis dan serosa, terlihat juga sel radang. Pada kelompok A didapatkan sel radangpada lapisan submukosa, metaplasia intestinal, dan pelebaran pembuluh darah. Pada kelompok B didapatkan sel radang, metaplasia intestinal dan pelebaran pembuluh darah.Pada kelompok C didapatkan erosi, sel radang, dan metaplasia intestinal dan pelebaran pembuluh darah.Pada kelompok D didapatkan nekrosis pada submukosa, sel radang, metaplasia intestinal dan hiperemi. Simpulan: Pemberian minuman beralkohol (bir, anggur, whisky, dan cap tikus) pada wistar dapat menyebabkan gastritis akut dan pada kadar alkohol yang tinggi (kadar alkohol 70\%) disertai dengan nekrosis lambung.

Kata Kunci: Bir, anggur, whisky, cap tikus, gastritis. 
Alkohol telah menjadi masalah global pada seseorang maupun terhadap lingkungan sosialnya. Penyalahgunaan alkohol menyebabkan kematian 2,5 juta setiap tehunnya (data WHO 2011), dan dari 320.000 orang berada pada usia 15-29 tahun dan merupakan 9\% dari kematian pada usia tersebut. ${ }^{(1)}$ Menurut riset yang dilakukan oleh riskesdas pada tahun 2007, di Indonesia daerah perkotaan ada 5 provinsi dengan prevalensi tinggi yaitu Gorontalo (19,6\%), Papua Barat (17,5\%), Sulawesi Tengah (15,2\%),Papua (14,0\%) dan Sulawesi Tenggara (13,4\%). Ada 2 provinsi dengan prevalensi sangat tinggi yaitu Sulawesi Utara (31,5\%), dan Nusa Tenggara Timur (21,2\%). Di pedesaan ada 8 provinsi dengan prevalensi tinggi yaitu Sulawesi Tengah $(14,1 \%)$, Sulawesi Tenggara (14,1\%), Maluku (12,8), Sumatra utara (12,6\%), Maluku utara $(12,0)$, Kalimantan Barat (11,3\%), Bali (11,2\%), dan Sulawesi Selatan (11,1\%). Kemudian ada 3 provinsi dengan prevalensi sangat tinggi yaitu Sulawesi Utara (32,9\%), Nusa Tenggara Timur (32,5\%), dan Gorontalo (27,6\%). ${ }^{(2)}$

Alkohol mengandung gugus hidroksil $\mathrm{OH}$, dan gugus hidroksil terikat pada karbon tetrahedral.Kandungan alkohol pada minuman keras adalah etanol dengan rumus molekulnya $\mathrm{C}_{2} \mathrm{H}_{5} \mathrm{O} .{ }^{(3)}$ Setelah dikonsumsi, etanol tanpa diubah diserap dalam lambung dan usus halus, kemudian tersebar ke semua jaringan dan cairan tubuh sesuai kadar di dalam darah. Sebagian besar alkohol dalam darah mengalami biotransformasi menjadi asetaldehida oleh alkohol dehydrogenase dalam sitosol sel hati dan mukosa lambung. ${ }^{(4)}$

Saluran

$$
\text { gastrointestinal }
$$

merupakan salah satu organ yang terkena pengaruh alkohol. Beberapa proses mendasari peran ini.Pertama, saluran GI adalah tempat penyerapan alkohol ke dalam aliran darah.Kedua, kontak langsung minuman beralkohol dapat menyebabkan banyak perubahan metabolik dan fungsional pada mukosa, perubahan ini dapat menyebabkan kerusakan mukosa, menimbulkan penyakit akut dan kronis, seperti perdarahan gastrointestinal akut (pada lambung atau usus kecil) dan diare.Ketiga, perubahan fungsional dan kerusakan mukosa usus mengganggu pencernaan nutrisi lainnya ada hubungan dengan kekurangan gizi dan penurunan berat badan yang sering diamati pada pecandu alkohol. Keempat, luka mukosa diinduksi alkohol terutama di bagian atas usus halus memungkinkan molekul besar, seperti endotoksin dan racun bakteri lainnya, untuk masuk lebih mudah ke dalam darah atau getah bening. Zat-zat beracun dapat memiliki efek merusak pada hati dan organ lainnya. ${ }^{(5)}$ Chari dkk pada tahun 1993 menganalisis di beberapa spesies hewan menemukan bahwa pemberian alkohol melalui mulut atau darah (intravena) dapat mempengaruhi sekresi asam lambung. Respon sekresi lambung bervariasi, tergantung pada spesies yang dipelajari dan konsentrasi alkohol yang digunakan. ${ }^{(5)}$ Penggunaan secara oral dan intervena dengan dosis yang mematikan (12 ml) dan subletal (8ml) pada alkohol murni menyebabkan gastritis hemoragik dan ulserasi superfisial terutama bagian distal lambung pada hewan coba anjing. ${ }^{(6)}$

\section{METODE PENELITIAN}

Penelitian ini merupakan penelitian eksperimental laboratorik dengan desain post test only pada kelompok perlakuan, dilakukan pada periode Oktober 2013Februari 2014 di Laboratorium Patologi Anatomi Fakultas Kedokteran Universitas Sam Ratulangi, Manado. Penelitian menggunakan 15 ekor wistar spesies rattus novergicus, jantan, berumur 3-4 bulan dengan berat rata-rata 200 gram, yang dibagi menjadi 5 kelompok, yaitu kelompok kontrol yang diberi air dan makan pelet standar, kelompok Ayang diberi bir 4,9\%, airdan makan pelet, kelompok Byang minuman anggur $14 \%$, air dan pelet, kelompok C yang diberi whisky 43\%,air, dan pelet, kelompok D yang diberi cap tikus $70 \%$, air, dan pelet.Sebelum dilakukan perlakuan semua kelompok diberi puasa selama 5 jam dan dilakukan uji coba selama 5 hari.Kelima kelompok diterminasi hari ke5. Minuman yang diberikan yaitu bir dengan 
kadar alkohol 4,9\% merek Anker, minuman anggur dengan kadar alkohol 14\% merek orang tua, whisky $43 \%$ dengan kadar alkohol merek mension house, dan cap tikus dengan kadar alkohol 70\% yang merupakan minuman tradisional khas Sulawesi Utara. Dosis 2,4 $\mathrm{ml}$ per tikus, diberikan secara intragastrik.

Perlakuan Hewan uji dilakukan selama 5 hari berturut-turut.Terminasi dilakukan pada hari ke 5 setelah kelompok perlakuan diberikan alkohol melalui intragastric. Tikus wistar dibedah dan selanjutnya diambil lambungnya untuk ditimbang dengan menggunakan timbangan elektrik digital. Parameter yang di nilai yaitu morfologi; makroskopik mengukur berat, warna, ada/tidaknya perdarahan lambung, dan secara mikroskopik dilihat adanya sel-sel neutrofil, edema ataupun erosi pada mukosa.

\section{HASIL PENELITIAN}

\section{Gambaran Makroskopik}

Pengamatan secara makroskopik dimulai saat terminasi melalui pengamatan ukuran, berat, warna, dan konsistensi. Berdasarkan pengamatan lambung tikus wistar, secara makroskopik warna lambung tikus wistar memiliki warna yang sama yaitu merah muda. Untuk konsistensi lambung, semuanya memiliki konsistensi lunak. Pada berat dan ukuran bervariasi antara satu kelompok dengan kelompok lainnya (Tabel 1).

Tabel 1. Gambaran Makroskopik lambung tikus wistar

\begin{tabular}{lllllr}
\hline No & Sampel & Warna & Konsistensi & Berat & Ukuran(PxLxT) \\
\hline $\mathbf{1}$ & Kontrol 1 & Merah muda & Kenyal & 1,04 & $2,5 \times 1,5 \times 0,6$ \\
$\mathbf{2}$ & Kontrol 2 & Merah muda & Kenyal & 1,01 & $2,5 \times 1,5 \times 0,6$ \\
$\mathbf{3}$ & Kontrol 3 & Merah muda & Kenyal & 1,02 & $2,5 \times 1,5 \times 0,6$ \\
$\mathbf{4}$ & Perlakuan A1 & Merah muda & Kenyal & 1,09 & $2,5 \times 1 \times 0,7$ \\
$\mathbf{5}$ & Perlakuan A2 & Merah muda & Kenyal & 1,06 & $3 \times 1 \times 0,7$ \\
$\mathbf{6}$ & Perlakuan A3 & Merah muda & Kenyal & 1,07 & $2,5 \times 0,7 \times 0,7$ \\
$\mathbf{7}$ & Perlakuan B1 & Merah muda & Kenyal & 1,1 & $2,5 \times 1,5 \times 0,7$ \\
$\mathbf{8}$ & Perlakuan B2 & Merah muda & Kenyal & 1,1 & $3 \times 1 \times 0,7$ \\
$\mathbf{9}$ & Perlakuan B3 & Merah muda & Kenyal & 1,2 & $3 \times 1 \times 0,7$ \\
$\mathbf{1 0}$ & Perlakuan C1 & Merah muda & Kenyal & 1,3 & $3 \times 1 \times 0,8$ \\
$\mathbf{1 1}$ & Perlakuan C2 & Merah muda & Kenyal & 1,5 & $3 \times 1,5 \times 0,7$ \\
$\mathbf{1 2}$ & Perlakuan C3 & Merah muda & Kenyal & 1,5 & $3 \times 2 \times 0,8$ \\
$\mathbf{1 3}$ & Perlakuan D1 & Merah muda & Kenyal & 1,6 & $3,5 \times 2 \times 0,8$ \\
$\mathbf{1 4}$ & Perlakuan D2 & Merah muda & Kenyal & 1,5 & $3,5 \times 2 \times 0,8$ \\
$\mathbf{1 5}$ & Perlakuan D3 & Merah muda & Kenyal & 1,8 & $3,5 \times 2 \times 0,8$ \\
\hline
\end{tabular}

\section{Kelompok kontrol}

Gambaran mikroskopik lambung tikus wistar yang hanya diberi air biasa dan pelet biasa selama 5 hari menunjukan lapisan dinding lambung yang normal. Tampak lapisan mukosa, submukosa, muskularis dan serosa. Terlihat sel-sel radang terutama pada lapisan submukosa (Gambar 1). 


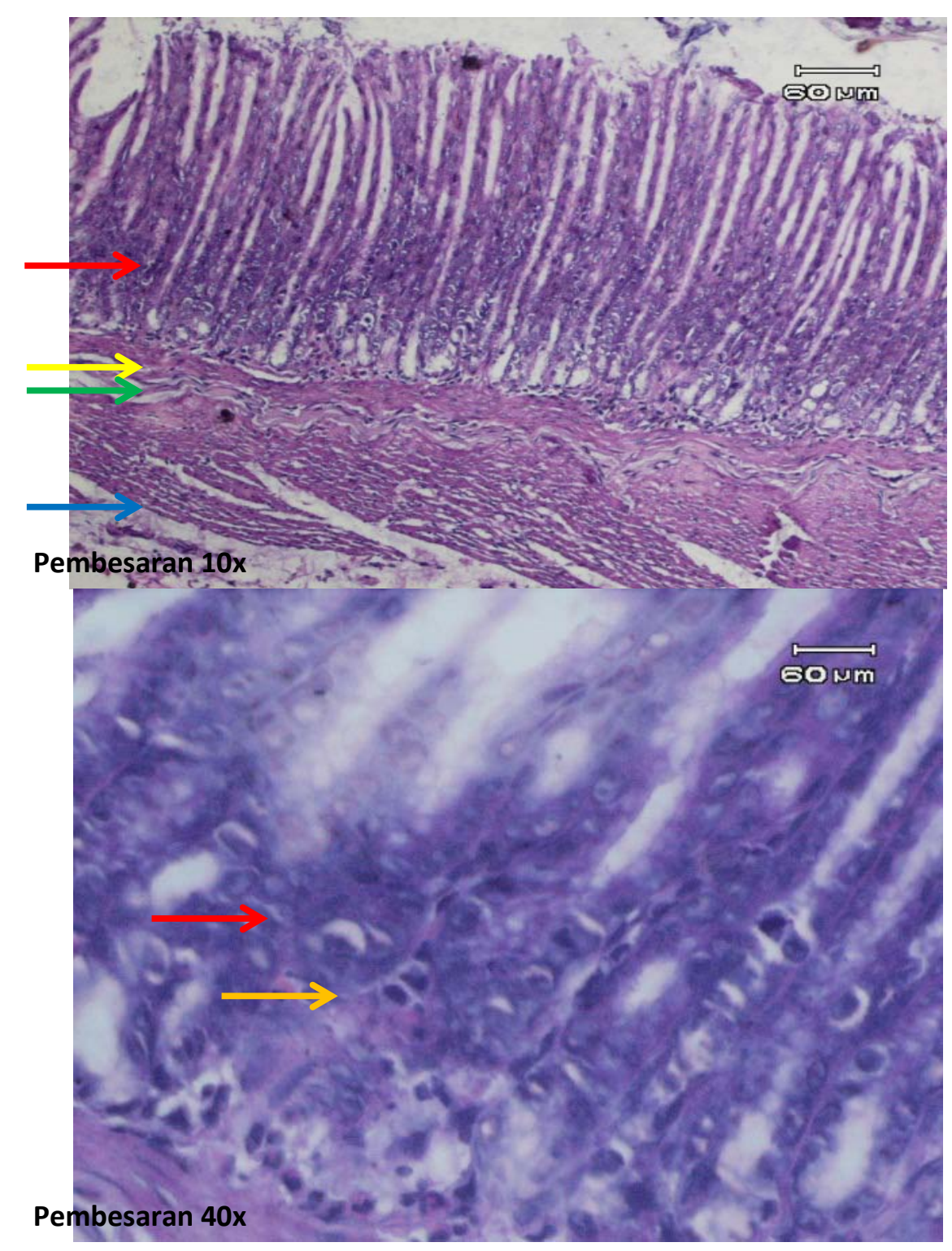

Gambar 1. Gambaran mikroskopik lambung tikus wistar kontrol pada pembesaran 10x dan 40x. Tampak lapisan mukosa(panah merah), submukosa (panah kuning), muskularis (panah hijau) dan serosa (panah biru). Terlihat pula adanya radang (panah jingga).

\section{Kelompok A}

Pada kelompok perlakuan yang diberikan bir pada konsentrasi alkohol 4,9\% selama 5 hari berturut-turut secara mikroskopik tidak terlihat adanya erosi, dan rugae masih ada. Tampak pada kelompok ini terdapat sel radang yang jauh lebih banyak daripada yang terdapat pada kelompok kontrol dan didominasi pada lapisan submukosa.Selain itu terlihat pula adanya metaplasia intestinal dan pelebaran pembuluh darah (Gambar 2). 

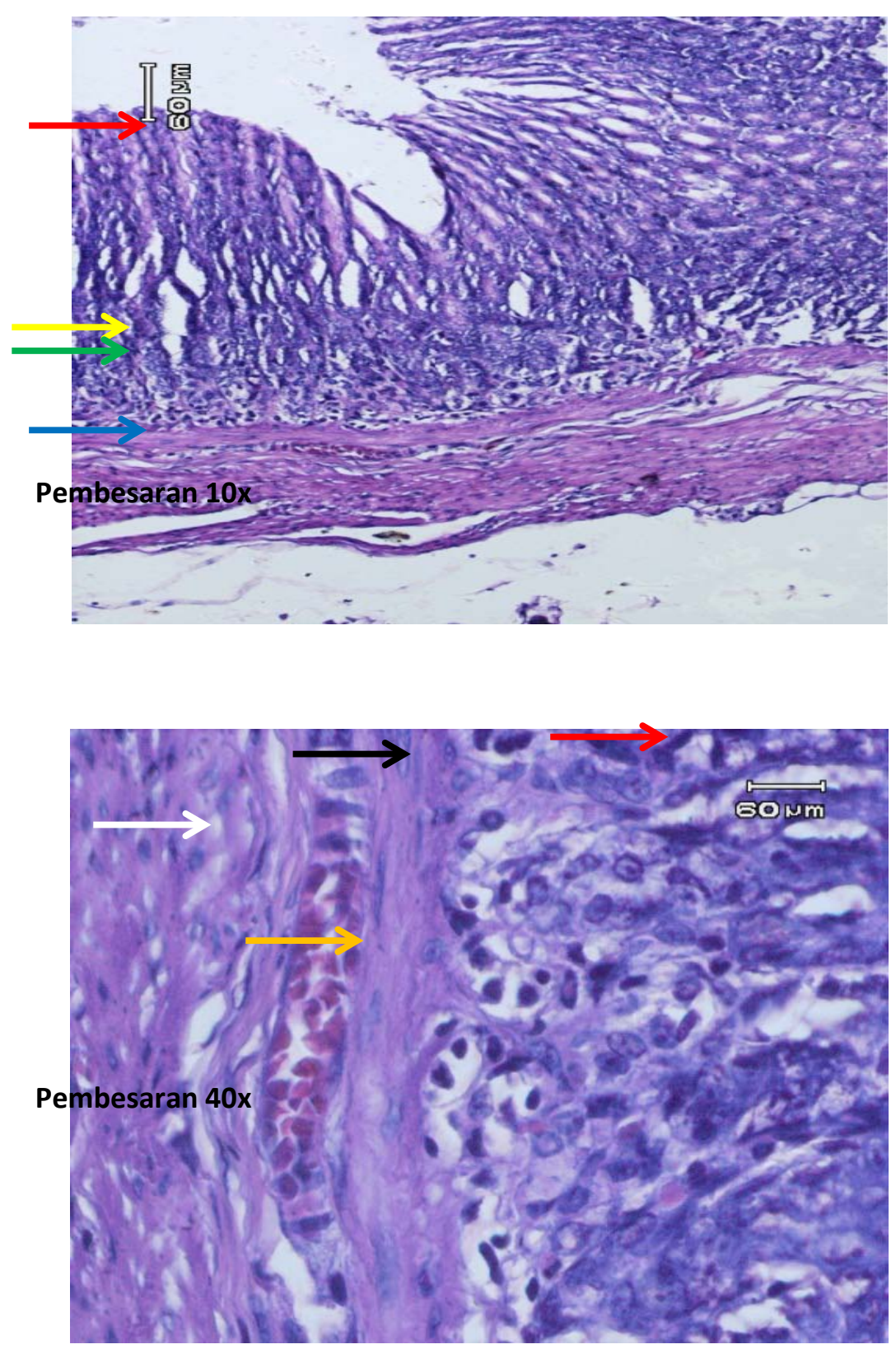

Gambar 2. Gambaran mikroskopik lambung tikus wistar perlakuan A pada pembesaran 10x dan 40x. Tampak lapisan mukosa(panah merah), submukosa (panah kuning), muskularis (panah hijau) dan serosa (panah biru). Tampak juga radang (panah jingga), pembesaran pembuluh darah (panah putih), dan metaplasia intestinal (panah hitam).

\section{Kelompok B}

Pada kelompok perlakuan yang diberikan minuman anggur pada konsentrasi alkohol $14 \%$ selama 5 hari berturut-turut secara mikroskopik tidak terlihat adanya erosi. Pada kelompok ini terlihat sel radang yang lebih banyak dari kelompok dengan perlakuan bir. Selain itu terlihat pula adanya metaplasia intestinal dan pelebaran pembuluh darah (Gambar 3).

\section{Kelompok C}

Pada kelompok perlakuan yang diberikan whiski pada konsentrasi alkohol 43\% selama 5 hari berturut-turut secara mikroskopik terlihat adanya erosi. Pada kelompok ini terlihat sel radang yang lebih banyak dari kelompok dengan 
perlakuan minuman anggur. Selain itu terlihat pula adanya metaplasia intestinal dan pelebaran pembuluh darah (Gambar 4).

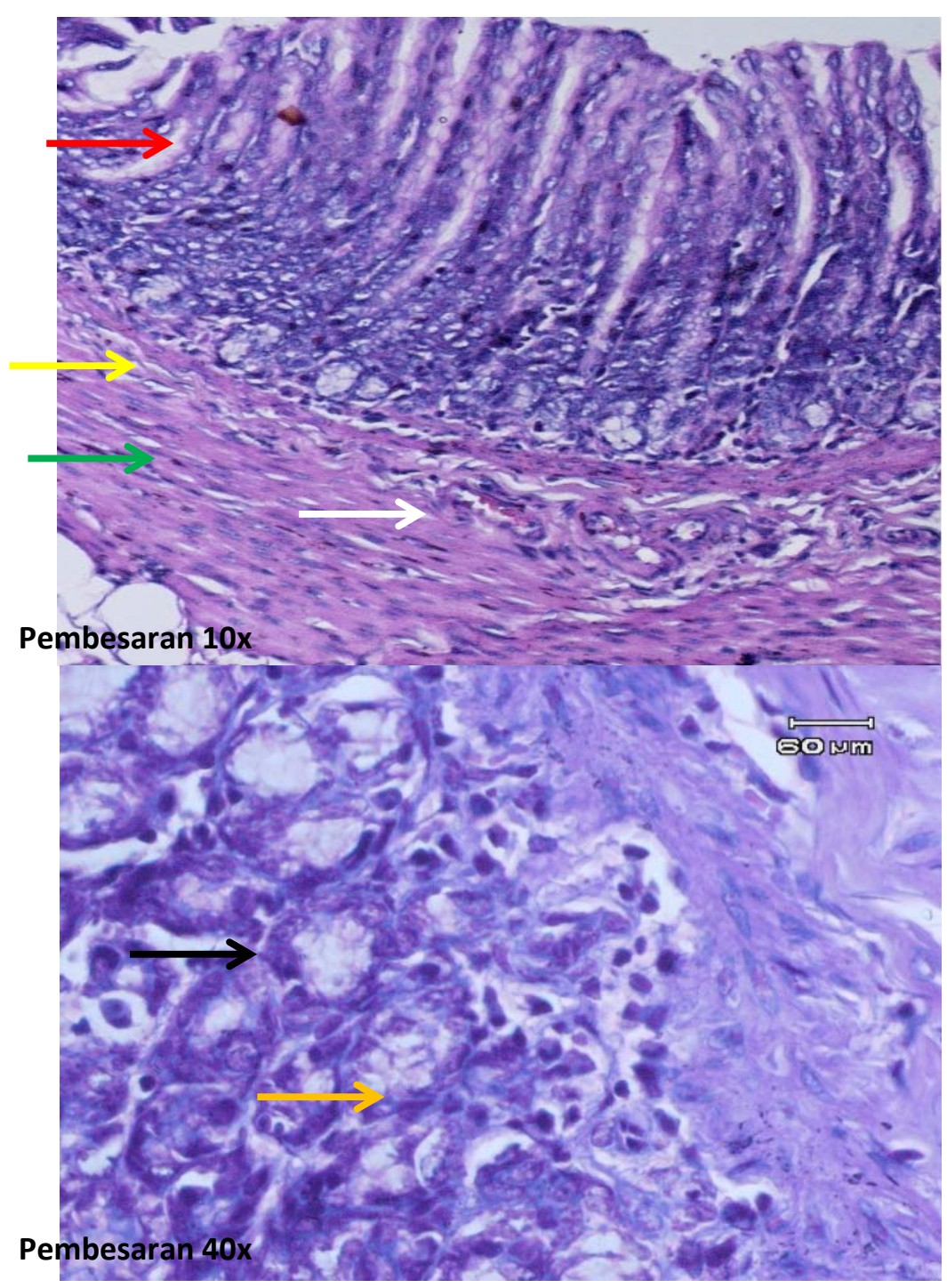

Gambar 3. Gambaran mikroskopik lambung tikus wistar Perlakuan B pada pembesaran 10x dan 40x. Tampak lapisan mukosa(panah merah), submukosa (panah kuning), dan muskularis (panah hijau). Tampak juga radang (panah jingga), pembesaran pembuluh darah (panah putih), dan metaplasia intestinal (panah hitam). 


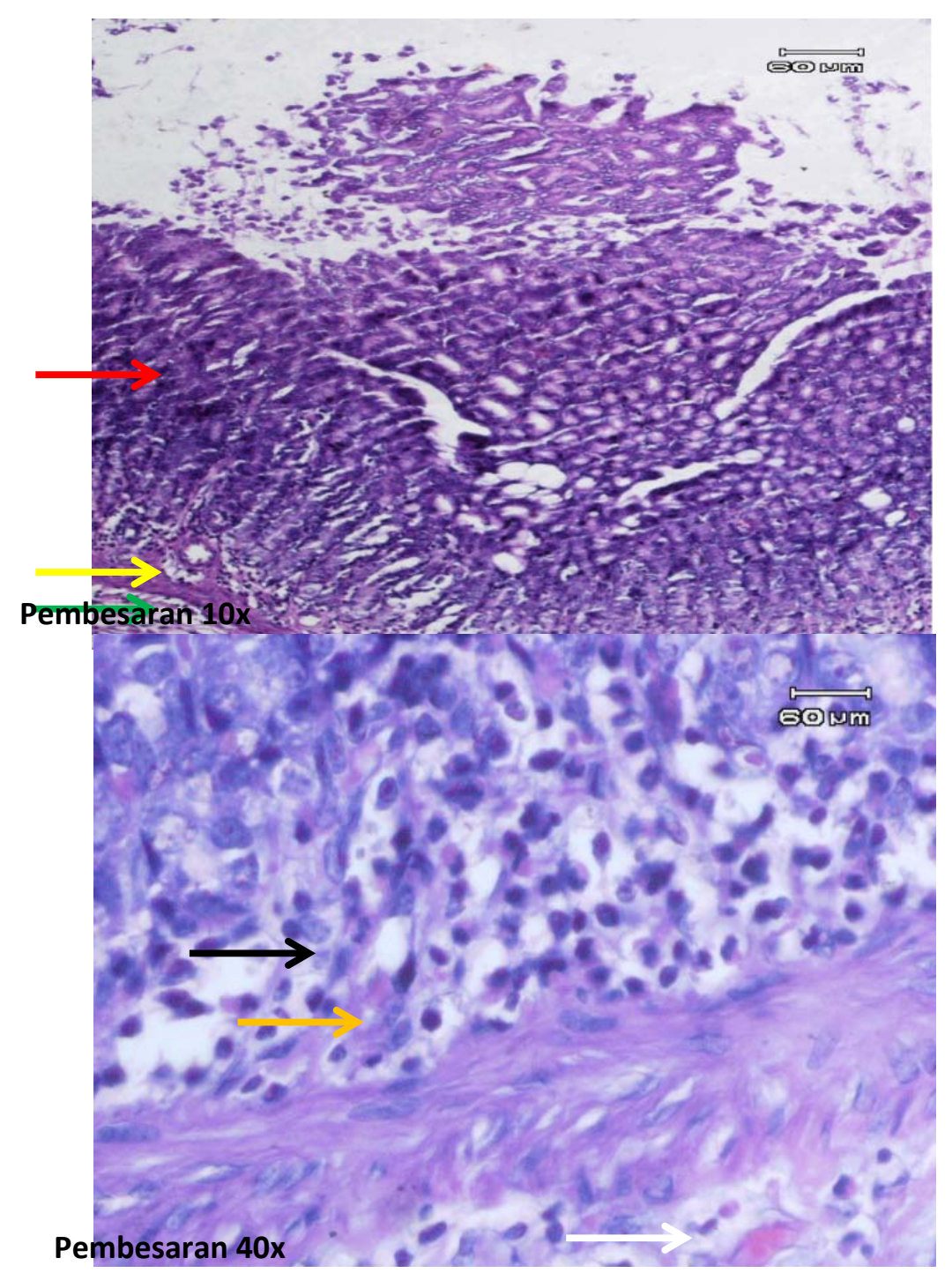

Gambar 4: Gambaran mikroskopik lambung tikus wistar Perlakuan C pada pembesaran 10x dan 40x. Tampak lapisan mukosa(panah merah), submukosa (panah kuning), dan muskularis (panah hijau). Tampak juga radang (panah jingga), pembesaran pembuluh darah (panah putih) dan metaplasia intestinal (panah hitam).

\section{Kelompok D}

Pada kelompok perlakuan yang diberikan cap tikus pada konsentrasi alkohol $70 \%$ selama 5 hari berturut-turut secara mikroskopik terlihat adanya nekrosis pada submukosa. Pada kelompok ini terlihat radang yang lebih banyak dari kelompok dengan perlakuan whiski. Selain itu terlihat pula adanya metaplasia intestinal dan hiperemi (Gambar 5). 

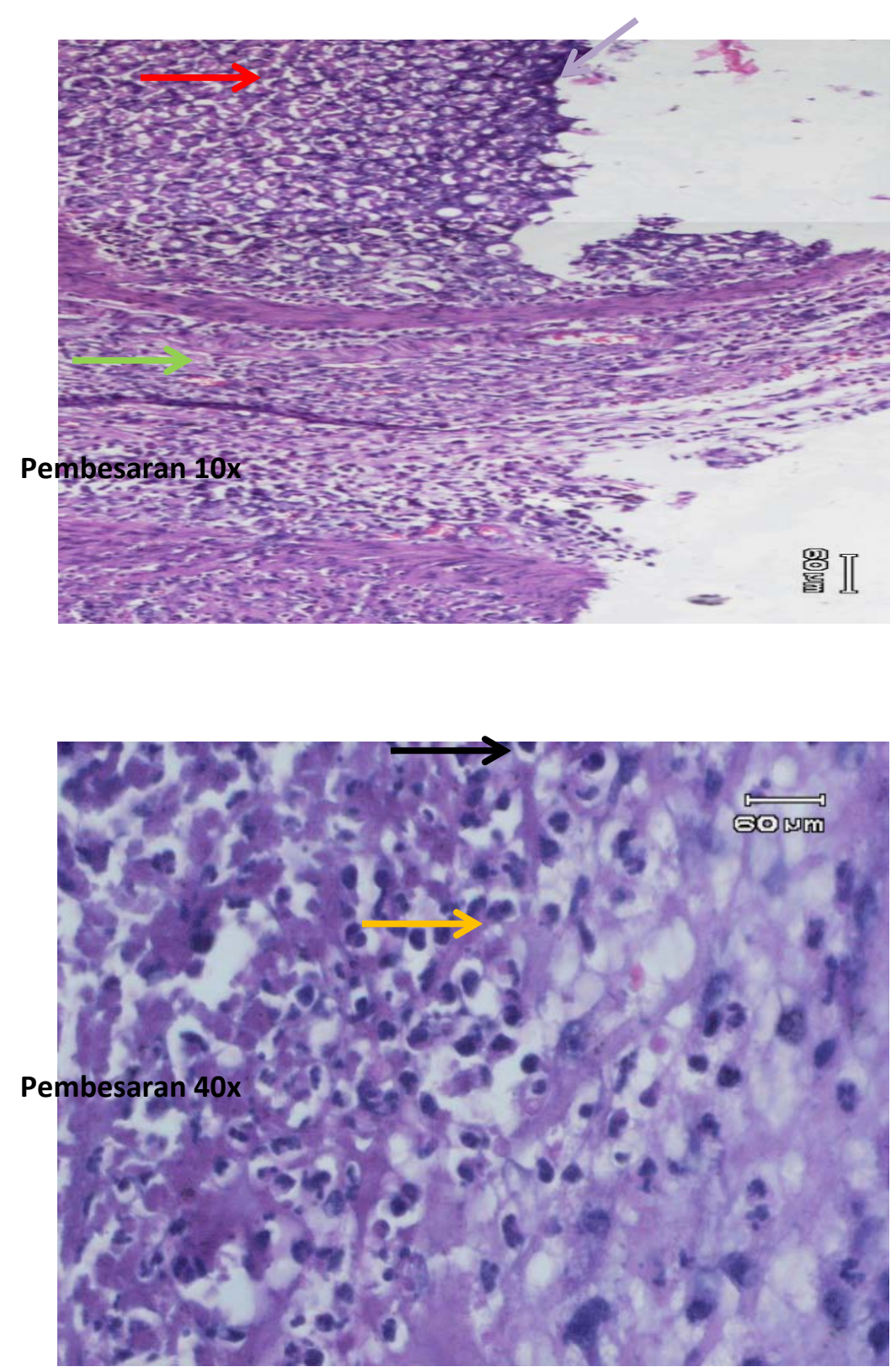

Gambar 5. Gambaran mikroskopik lambung tikus wistar Perlakuan D pada pembesaran 10x.. Tampak lapisan mukosa(panah merah), erosi (panah ungu), radang (panah jingga), metaplasia intestinal (panah hitam) dan nekrosis (hijau muda).

\section{BAHASAN}

Alkohol memiliki efek pada setiap organ dalam tubuh, dan efek ini tergantung pada konsentrasi alkohol dalam darah. Kira-kira $10 \%$ alkohol yang dikonsumsi diabsorbsi di lambung dan sisanya diabsorbsi di usus halus. ${ }^{(7)}$ Saluran gastrointestinal merupakan salah satu organ yang paling berpengaruh terhadap efek alkohol. ${ }^{(5)}$

Secara makroskopik warna dan konsistensi kelompok kontrol dan perlakuan, tidak terlihat adanya perbedaan. Hasil pengukuran terhadap panjang, lebar, tinggi dan berat terdapat peningkatan seiring dengan tingginya kadar alkohol (Tabel 1). Konsumsi alkohol dapat menyebabkan kerusakan pada permukaan lambung, hal ini dapat dibuktikan pada hewan coba. Pada penelitian ini pemberian alkohol dari tingkat rendah sampai tinggi pada tikus wistar 
dewasa dalam jangka waktu 5 hari menyebabkan kerusakan lambung, yang secara mikroskopik menunjukan gastritis akut. Hal ini sesuai dengan penelitian yang dilakukan oleh Bode dan Bode pada tahun 1992 tentang malnutrisi karna alkohol dan saluran gastrointestinal menyebutkan bahwa konsentrasi alkohol 10 persen atau lebih mengganggu pertahanan mukosa lambung dan meningkatkan permeabilitas pembuluh darah kapiler mukosa. ${ }^{(5)}$

Kontak alkohol pada permukaan lambung mengganggu sekresi mukosa dan merusak sel epitel, hal ini dapat menyebabkan nekrosis sehingga lapisan mukosa terekspos dengan alkohol dan asam lambung.Pada sediaan mikroskopik pada kelompok perlakuan didapatkan kerusakan akibat alkohol bertambah seiring dengan tingginya kadar alkohol. Terlihat jumlah sel radang bertambah banyak seiring dengan tingginya kadar alkohol dalam minuman. Selain itu terdapat pula pelebaran pembuluh darah pada setiap kelompok perlakuan, yaitu pada perlakuan bir, minuman anggur,whisky dan cap tikus (gambar 1- gambar 5).

Penelitian yang dilakukan oleh Chari dan kawan-kawan pada tahun 1993 tentang efek minuman beralkohol, pada asam lambung dan sekresi gastrin menunjukan bahwa bir dan minuman anggur merah ataupun minuman anggur putih merangsang sekresi asam dan melepaskan gastrin, sedangkan pada minuman berkonsentrasi tinggi (seperti whisky, gin atau brendy) tidak merangsang sekresi asam atau pelepasan gastrin. ${ }^{(8)}\left({ }^{(9)}\right.$ Pada penelitian ini secara mikroskopik pada kelompok perlakuan yang diberikan bir pada konsentrasi alkohol 4,9\% dan pada kelompok perlakuan yang diberikan minuman anggur pada konsentrasi alkohol $14 \%$ tidak terlihat adanya erosi, dan rugae masih ada. Jumlah sel radang terlihat pada kelompok perlakuan minuman anggur lebih banyak daripada kelompok perlakuan bir.Selain itu terlihat pula adanya metaplasia intestinal dan pelebaran pembuluh darah. Hal ini menunjukan telah terjadi gastritis akut yang kemungkinan disebabkan oleh peningkatan asam lambung yang berlebihan.
Konsumsi alkohol pada konsentrasi lebih dari 25\% mengubah mukosa lambung, selain itu alkohol dapat memiliki kemungkinan mengubah gradient $\mathrm{pH}$ di seluruh lapisan mukosa. ${ }^{(8)}$ Secara mikroskopik kelompok perlakuan yang diberikan whiski pada konsentrasi alkohol $43 \%$ terlihat adanya erosi, sel radang yang lebih banyak dibandingkan dengan kelompok perlakuan minuman anggur $14 \%$. Selain itu terlihat pula adanya metaplasia intestinal dan pelebaran pembuluh darah. Dan pada kelompok yang diberikan cap tikus dengan kadar alkohol $70 \%$, terlihat adanya hipermi, perdarahan dan bagian yang telah terjadi nekrosis dan erosi. Hal ini sesuai dengan penelitian yang dilakukan oleh Beazell dan Ivy (1940) menyebutkan bahwa penyalahgunaan alkohol dapat merusak mukosa lambung dan merupakan penyebab penting perdarahan. ${ }^{(5)}$

\section{SIMPULAN}

Pemberian minuman beralkohol (bir, anggur, whisky, dan cap tikus) pada tikus wistar dapat menyebabkan gastritis akut.Dan pada perlakuan cap tikus dengan kadar alkohol $70 \%$ terjadi gastritis akut erosif dan nekrosis.

\section{SARAN}

Perlunya penambahan jumlah sampel untuk penelitian lebih lanjut dan dibutuhkan waktu penelitian lebih lama untuk melihat efek dari penggunaan alkohol jangka panjang.

\section{UCAPAN TERIMA KASIH}

Ucapan terima kasih kepada dr. Youla Assa, M.Kes dan dr. Meilany Durry, MKes,SpPA, serta semua pihak yang secara langsung maupun tidak langsung yang telah memberi ide maupun gagasan kepada penulis sehingga penulis dapat menyelesaikan artikel ini.

\section{DAFTAR PUSTAKA}

1. World Health Organization. Alcohol. 2011 
Feb [Cited 2013 Okt]. Available from: http://www.who.int/mediacentre/factsheets/f s349/en/

2. Suhardi. Preferensi Peminum Alkohol di Indonesia Menurut Riskesdas 2007. Pusat Teknologi Terapan Kesehatan dan Epidemiologi Klinik. 2011.

3. Fessenden RJ, Fessenden JS. Alcohol, tiol, fenol. Dasar-dasar kimia organik. Jakarta: Binarupa Aksara; 1997.p.306-307.

4. Kumar V, Cotran R, Robbins S. Buku ajar Patologi. 7th ed. Jakarta: EGC; 2007.p.314,4,11-12,36-37.

5. Bode C, Bode JC. Alcohol's Role in Gastrointestinal Tract Disorders. Alcohol Health \& Reasearch world. 1997; 21:76-83.
6. Anderson. Drug and chemical injury. Pathology. Missory: Morby Company; 1971.p.205.

7. Kaplan H, Sadock B, Grebb J. Gangguan berhubungan dengan zat. Sinopsis psikiatri. Tangerang: Binarupa Aksara; 2010.p.605,610.

8. Bujuanda L. The effect of alcohol consumption upon the gastrointestinal track. The American Journal of Gastroenterologi. 2000;95

9. Chari S, Teyssen S, Singer MV. Alcohol and gastric acid secretion in humans. Germany: Uneversity Hospital of Heidelberg at Mannheim, Medicine IV (Gastroenterology); 1999. 